\title{
High potential, but low actual, glycine uptake of dominant plant species in three Australian land-use types with intermediate $\mathbf{N}$ availability
}

\author{
Ansgar Kahmen • Stephen J. Livesley • \\ Stefan K. Arndt
}

Received: 8 November 2008 / Accepted: 5 March 2009/Published online: 18 March 2009

(C) The Author(s) 2009. This article is published with open access at Springerlink.com

\begin{abstract}
The traditional view of the nitrogen (N) cycle has been challenged since the discovery that plants can compete with microbes for low molecular weight (LMW) organic N. Despite a number of studies that have shown LMW organic $\mathrm{N}$ uptake by plants, there remains a debate on the overall ecological relevance of LMW organic $\mathrm{N}$ uptake by plants across ecosystems with different $\mathrm{N}$ availabilities. We here report patterns of glycine $\mathrm{N}$ uptake by plants from three different Australian land-use types with intermediate $\mathrm{N}$ availability and low inherent glycine concentrations in the soil. Using ${ }^{15} \mathrm{~N}$ labeled tracers, we tested the potential of these plants to acquire glycine in ex-situ laboratory experiments and attempted to validate these results in the field by determining actual uptake of glycine by
\end{abstract}

Responsible Editor: A. C. Borstlap.

A. Kahmen $\cdot$ S. J. Livesley $\cdot$ S. K. Arndt

Department of Forest and Ecosystem Science,

The University of Melbourne,

Melbourne, Australia

A. Kahmen

Institute of Plant Sciences, ETH Zurich,

Zurich, Switzerland

Present address:

A. Kahmen $(\bowtie)$

Center for Stable Isotope Biogeochemistry,

Department of Integrative Biology,

University of California, Berkeley,

CA 94720-3140, USA

e-mail: akahmen@berkeley.edu plants directly from the soil. We found in the ex-situ experiments that plants from all three land-use types were able to take up significant amounts of glycine. In contrast, glycine uptake directly from the soil was minimal in all three land-use types and ${ }^{15} \mathrm{~N}$ tracers were largely immobilized in the soil organic $\mathrm{N}$ pool. Our study confirms that the potential for LMW organic $\mathrm{N}$ uptake by plants is a widespread phenomenon. However, our in-situ experiments show that in the three land-use types tested here plants are inferior competitors for LMW organic $\mathrm{N}$ and rely on $\mathrm{NH}_{4}{ }^{+}$as their main $\mathrm{N}$ source. In contrast to several previous studies in arctic, alpine and even temperate ecosystems, our study suggests that in ecosystems with intermediate $\mathrm{N}$ availability, mineral $\mathrm{N}$ is the plants' main $\mathrm{N}$ source, while LMW organic $\mathrm{N}$ is of less ecological relevance to plant $\mathrm{N}$ nutrition.

Keywords Amino acids · Glycine $\cdot$ Microbial competition · Mineral nutrition · Stable isotopes

\section{Introduction}

The nitrogen $(\mathrm{N})$ cycle is an essential element of ecosystem biogeochemistry (Vitousek and Howarth 1991; Vitousek et al. 1997b). A profound understanding of the $\mathrm{N}$ cycle is therefore important to evaluate and predict the consequences of globally increasing $\mathrm{N}$ deposition for the structure and function of ecosystems (Vitousek et al. 1997a). Historically, microbial N 
mineralization in the soil had been viewed as the most critical aspect of the $\mathrm{N}$ cycle. In this traditional concept only $\mathrm{N}$ that was mineralized by microbes in excess of their own demand and released back into the soil (i.e. net $\mathrm{N}$ mineralization) was available to plants. As a consequence, net $\mathrm{N}$ mineralization was considered the key process that controlled $\mathrm{N}$ availability for plants (Haynes and Goh 1978; Kinzel 1982; Runge 1970). This classic view of the $\mathrm{N}$ cycle has been challenged over the past years by a number of studies that have shown the potential of plants to circumnavigate the mineralization bottleneck in the $\mathrm{N}$ cycle by effectively taking up intact forms of low molecular weight (LMW) organic N, such as amino acids (Bardgett et al. 2003; Chapin et al. 1993; Näsholm et al. 1998; Schimel and Bennett 2004).

Originally, LMW organic N uptake by plants was tested under laboratory conditions. These experiments revealed that the potential for LMW organic $\mathrm{N}$ uptake is a widespread phenomenon of plant species from a broad range of different ecosystems (FalkengrenGrerup et al. 2000; Finzi and Berthrong 2005; Kielland 1994; Raab et al. 1999; Schmidt and Stewart 1999; Warren and Adams 2007; Weigelt et al. 2005). Plants in laboratory experiments are, however, removed from their ecological context where they have to cope with microbial competition, abiotic immobilization of nutrients and where they are deprived of their mycorrhizal associations. A number of studies have therefore tested the uptake of LMW organic $\mathrm{N}$ by plants directly from the soil, either in pots or in-situ in intact ecosystems. To date we have evidence for LMW organic $\mathrm{N}$ uptake directly from the soil by plants from arctic (Clemmensen et al. 2008; Nordin et al. 2004), alpine (Miller et al. 2007), tundra (McKane et al. 2002; Schimel and Chapin 1996) and boreal ecosystems (Näsholm et al. 1998; Nordin et al. 2001; Persson et al. 2003) as well as from improved and unimproved temperate grasslands (Bardgett et al. 2003; Harrison et al. 2007; Streeter et al. 2000) and agricultural soils (Näsholm et al. 2000, 2001; Xu et al. 2008).

Despite a growing body of literature that reports LMW organic $\mathrm{N}$ utilization by plants, the ecological relevance of LMW organic $\mathrm{N}$ uptake by plants in different ecosystems is still controversial (Jones et al. 2005). In particular, strong microbial competition for mineral N, and especially for LMW organic N, seems to conflict with observations of plant LMW organic N uptake (Finzi and Berthrong 2005; Hodge et al. 2000;
Jackson et al. 1989; Kaye and Hart 1997; Lipson and Monson 1998; Lipson et al. 1999; Schimel et al. 1989; Sorensen et al. 2008). Compared to plant roots, microbes have better substrate affinity, higher mobility in the soil and a higher surface to mass ratio and should therefore out compete plants for LMW organic N (Owen and Jones 2001). Schimel and Bennett (2004) therefore proposed that the main form of $\mathrm{N}$ taken up by plants varies across a gradient of increasing $\mathrm{N}$ availability and microbial competition and depends on the distribution of $\mathrm{N}$-rich micro sites in the soil. For example, in extremely $\mathrm{N}$ poor ecosystems such as some boreal, arctic or alpine ecosystems as well as in acidic grasslands decomposition and mineralization rates are low so that plants and microbes have to compete for LMW organic $\mathrm{N}$ to meet their $\mathrm{N}$ demands. Given their competitive strength microbes would win the majority of the competition for amino acids while plants would capture only a small but constant proportion of LMW organic N. However, the slow growth and longevity of plants in these ecosystems combined with their potential to effectively retain $\mathrm{N}$ could allow a small but consistent uptake of LMW organic $\mathrm{N}$ to meet the overall $\mathrm{N}$ demand of these plants. In ecosystems with greater $\mathrm{N}$ availability, microbes would be less $\mathrm{N}$ limited and begin to mineralize organic $\mathrm{N}$ to $\mathrm{NH}_{4}^{+}$. However, mineralization would be restricted to N-rich micro sites and LMW organic $\mathrm{N}$ and $\mathrm{NH}_{4}^{+}$would diffuse away from the mineralization micro sites into the soil where plants and microbes would actively compete for it. Under such conditions, plants would have access to some LMW organic $\mathrm{N}$ but their nutrition would mainly rely on $\mathrm{NH}_{4}{ }^{+}$. With increasing $\mathrm{N}$ availability, microbial demand would be increasingly satisfied by LMW organic $\mathrm{N}$ in the microsites, reducing the competition between plants and microbes for diffusing $\mathrm{NH}_{4}{ }^{+}$. Eventually denitrifiers would become established and plant $\mathrm{N}$ capture would increasingly rely on $\mathrm{NH}_{4}{ }^{+}$and $\mathrm{NO}_{3}{ }^{-}$as suggested in the classic view of the $\mathrm{N}$ cycle (Schimel and Bennett 2004).

The large number of studies that have reported LMW organic $\mathrm{N}$ uptake by plants in arctic, alpine, boreal ecosystems as well as in unimproved grasslands on acidic soils (see references cited above) give credible evidence for the low end of the $\mathrm{N}$ availability gradient along Schimel and Bennett's model. Also, Nordin et al. (2001) and Bardgett et al. (2003) demonstrated that the main form of $\mathrm{N}$ taken up by plants does in fact vary across a gradient of increasing $\mathrm{N}$ availability as hypothesised. In their studies LMW organic N uptake 
decreases at the expense of inorganic $\mathrm{N}$ uptake along a boreal forest productivity gradient and along the transition of an unimproved acidic soil to agriculturally improved grassland, respectively. Alternatively, studies made at the high $\mathrm{N}$ end of the $\mathrm{N}$ availability gradient have shown LMW organic $\mathrm{N}$ uptake by plants in heavily fertilized agricultural ecosystems, where competition between plants and microbes for soil $\mathrm{N}$ is limited (Näsholm et al. 2001; Xu et al. 2008). Given ample evidence from either end of this $\mathrm{N}$ availability gradient, it is remarkable that very little information for LMW organic $\mathrm{N}$ uptake by plants is available from ecosystems with intermediate $\mathrm{N}$ availability where net $\mathrm{N}$ mineralization occurs (in contrast to high latitude or alpine ecosystems) but where ecosystems are not $\mathrm{N}$ saturated (in contrast to agricultural ecosystems or locations with large inputs from atmospheric deposition). For a full understanding of the underlying basic ecological mechanisms, as well as for the overall ecological relevance of organic LMW $\mathrm{N}$ uptake for plants across a broad range of ecosystems, investigations in ecosystems with intermediate $\mathrm{N}$ availability are now critically important.

In the study presented here, we tested LMW organic $\mathrm{N}$ uptake of plants in relation to mineral $\mathrm{N}$ uptake in three different Australian land-use types with intermediate N availability: a Pinus radiata plantation, a Eucalyptus globulus plantation and a grassland pasture. Specifically, we used the amino acid glycine as an indicator of LMW organic N uptake and tested (1) the overall potential of the plants to take up glycine relative to mineral $\mathrm{N}$ in ex-situ root incubation experiments. Further, (2) we determined actual glycine uptake relative to mineral $\mathrm{N}$ uptake directly from the soil in the presence of abiotic immobilization and microbial competition. Finally, (3) we determined the recovery rates of glycine ${ }^{15} \mathrm{~N}$ tracers over time, as well as mineral ${ }^{15} \mathrm{~N}$ tracers, in different compartments of the ecosystems such as plant roots, mineral $\mathrm{N}$ pools and the immobile soil organic $\mathrm{N}$ pool.

\section{Methods}

\section{Study area}

The study area was located near Dereel $\left(37^{\circ} 49^{\prime} \mathrm{S}, 143^{\circ}\right.$ $\left.45^{\prime} \mathrm{E}\right), 20 \mathrm{~km}$ south of Ballarat in the state of Victoria in south-eastern Australia. The climate in this area is temperate, with an annual rainfall of $700 \mathrm{~mm}$ and mean monthly maximum temperatures ranging from 11$25^{\circ} \mathrm{C}$. Sample plots (ca 0.25 ha, $n=5$ ) were established in three adjacent land uses types that are common the south eastern part of Australia: a perennial grassland pasture, a $P$. radiata plantation established on pasture in 1994 and an E. globulus plantation established on pasture in 1999. The three land-use types were all located within a $50 \mathrm{~m}$ radius. The grassland was an improved pasture that was dominated by the grass species Agrostis capillaris L., Holcus lanatus L. and Anthoxanthum odoratum L. and contained a number of native Australian grassland species (Hypericum graminea G. Forst, Aceana echinata Nees, Austrodanthonia $s p$ ) and typical pastoral herbs (Hypochaeris radicata L., Taraxacum officinale Weber ex F.H.Wigg, Trifolium $s p$. and Oxalis sp.). The two plantations were both established after soil ripping, mounding and an initial fertiliser addition. By the time of the experiment both plantations had achieved a closed canopy with an approximate height of $12 \mathrm{~m}$ (pine) and $15 \mathrm{~m}$ (eucalyptus). The topography is gently undulating, and the soil type in the upper $10 \mathrm{~cm}$ is classed as a silt loam (USDA) with $11-16 \%$ clay and $10-17 \%$ silt.

Uptake of mineral and glycine ${ }^{15} \mathrm{~N}$ by roots

In February 2005, root uptake of ${ }^{15} \mathrm{NO}_{3}{ }^{-},{ }^{15} \mathrm{NH}_{4}{ }^{+}$and ${ }^{15} \mathrm{~N}$-glycine by E. globulus (Eucalyptus plantation), $P$. radiata (Pine plantation) and grassland plants (not separated by species) was studied using three different approaches. We studied the ${ }^{15} \mathrm{~N}$ uptake of 1) excavated but intact roots in the field (ex-situ attached roots), 2) excavated and detached roots in the lab (ex-situ excised roots), and 3) intact and in-situ rhizosphere roots by injecting ${ }^{15} \mathrm{~N}$ labeled solutions into the soil (in-situ ecosystem $\mathrm{N}$ uptake). We specifically applied three different methods to test for different aspects of root ${ }^{15} \mathrm{NO}_{3}{ }^{-},{ }^{15} \mathrm{NH}_{4}{ }^{+}$and ${ }^{15} \mathrm{~N}$-glycine uptake. With the two ex-situ methods we tested the plant's potential uptake capabilities for the different $\mathrm{N}$ species when provided in solution at similar concentrations. In addition, we tested the plant's actual $\mathrm{N}$ uptake patterns under more realistic in-situ conditions where plants have to cope with abiotic immobilization and microbial competition, as well as the different concentrations the three $\mathrm{N}$ species are available at. Therefore, the concentrations of the ${ }^{15} \mathrm{~N}$ species injected into the soil in the in situ 
experiments were adjusted to only fractionally increase $(\sim 10 \%)$ the in-situ concentrations of $\mathrm{NO}_{3}{ }^{-}, \mathrm{NH}_{4}{ }^{+}$and glycine measured in the soil at the time of the experiments (Murphy et al. 2003).

$\mathrm{N}$ uptake by excavated but intact roots

To study the ${ }^{15} \mathrm{~N}$ uptake of attached roots we carefully excavated root tips of $P$. radiata and E. globulus in the upper $5 \mathrm{~cm}$ of the soil in each of the five blocks in the two plantations, (one root tip for ${ }^{15} \mathrm{NO}_{3}{ }^{-},{ }^{15} \mathrm{NH}_{4}{ }^{+}$and ${ }^{15} \mathrm{~N}$-glycine uptake, replicated five times in each of the two plantations). Excavation of individual roots in the grassland was not possible because plants developed a thick root layer and roots that were too fragile to be excavated while still attached to the plant. After washing the excavated roots with water, root tips were incubated in $10.0 \mathrm{~mL}$ of nutrient solution. The solution contained 60 atom $\%{ }^{15} \mathrm{NO}_{3}{ }^{-}$, 60 atom $\%{ }^{15} \mathrm{NH}_{4}{ }^{+}, 99.9$ atom $\%{ }^{15} \mathrm{~N}$-glycine. The roots were simultaneously offered all three $\mathrm{N}$ sources in one solution at a concentration of $100 \mu \mathrm{mol} \mathrm{N} \mathrm{L} \mathrm{N}^{-1}$ each, to provide comparable access to different $\mathrm{N}$ sources, whilst only ${ }^{15} \mathrm{~N}$ labeling one $\mathrm{N}$ source. In addition, $\mathrm{N}$ uptake solutions contained $10 \mathrm{mg} \mathrm{L}^{-1}$ ampicillin to minimize microbial activity in the uptake solutions and $100 \mu \mathrm{mol} \mathrm{L} \mathrm{L}^{-1} \mathrm{CaCl}_{2}$ for membrane stability. Ampicillin has been shown to effectively inhibit bacterial growth and $\mathrm{N}$ mineralization in similar experiments (Warren 2006; Warren and Adams 2007). We are therefore confident that the ${ }^{15} \mathrm{~N}$ recovered in plant roots in the ${ }^{15} \mathrm{~N}$-glycine treatment originated from the uptake of intact glycine. After $2 \mathrm{~h}$ of incubation, the submerged root tip, and the first $10 \mathrm{~mm}$ of the unsubmerged root, were cut and washed in $50 \mathrm{mM}$ $\mathrm{KCl}$ and then deionized water. Roots were then dried at $80^{\circ} \mathrm{C}$ for $48 \mathrm{~h}$, ground to a fine powder and analyzed by a continuous flow isotope ratio mass spectrometer (IRMS, IsoPrime, GV-Instruments, Manchester, UK).

$\mathrm{N}$ uptake by excavated and detached roots

The ${ }^{15} \mathrm{~N}$ uptake of excised roots was studied on the same day as ${ }^{15} \mathrm{~N}$ uptake of attached roots. We collected five soil cores $(50 \times 50 \mathrm{~mm})$ in each of the three different land use types. The soil cores were kept on ice whilst transported back to the laboratory within $2 \mathrm{~h}$ of sample collection and roots were separated from the soil by sieving and washing in deionised water. From each core roots were then incubated in $10 \mathrm{~mL}$ of the same labeled nutrient uptake solution as described above. After $1 \mathrm{~h}$ of incubation the roots were washed with $50 \mathrm{mM} \mathrm{KCl}$ and deionised water to remove excess nutrient solution, dried at $80^{\circ} \mathrm{C}$ for $48 \mathrm{~h}$, ground to a fine powder and analyzed by IRMS.

$\mathrm{N}$ uptake by attached and excised roots from the solution cultures was calculated as $\mu \mathrm{mol}{ }^{15} \mathrm{~N}$ excess per gram dry root weight compared to $\mu \mathrm{mol}{ }^{15} \mathrm{~N}$ in control roots. Since we used 99.9 atom $\%{ }^{15} \mathrm{~N}$-glycine for labeling the solutions $\mu$ mol ${ }^{15} \mathrm{~N}$ excess ${ }^{15} \mathrm{~N}$-glycine reflects the molar uptake rates for these $\mathrm{N}$ species. For nitrate and ammonium uptake, we used 60 atom \% ${ }^{15} \mathrm{NO}_{3}{ }^{-}$and 60 atom $\%{ }^{15} \mathrm{NH}_{4}^{+}$. Consequently, we multiplied $\mu \mathrm{mol}{ }^{15} \mathrm{~N}$ excess ${ }^{15} \mathrm{NO}_{3}{ }^{-}$and $\mathrm{NH}_{4}{ }^{+}$with $100 / 60$ in our calculations of $\mathrm{N}$ uptake.

$\mathrm{N}$ uptake by intact and in-situ roots

The uptake of ${ }^{15} \mathrm{~N}$ by roots from their rhizosphere environments was studied in the same week as the other uptake approaches. Fifteen large $(250 \mathrm{~mm}$ diameter) plastic soil collars were installed in each of the three land-use types. The litter layer around the circumference of the collar was cut, and the collar slightly inserted into the soil so that the litterfermentation layer remained intact and the roots were not disturbed inside the collar. In order to create comparable soil moisture conditions within, but also across, the three different land-use types and to minimize disturbance from the injection of $\mathrm{N}$ solutions into the soil, the collars were slowly (over $1 \mathrm{~h}$ ) irrigated with $9.0 \mathrm{~L}$ of deionized water 3 days before the experiment, so that the upper five $\mathrm{cm}$ of soil was saturated and could then drained back to field capacity. Three days later, two soil cores $(50 \mathrm{~mm}$ diameter, $50 \mathrm{~mm}$ deep) were inserted into the soil inside each collar. One core was sampled immediately to determine soil water content $\left(48 \mathrm{~h}\right.$ at $\left.105^{\circ} \mathrm{C}\right)$, inorganic $\mathrm{N}$ concentration $(1: 4$, soil: $1 \mathrm{M} \mathrm{KCl}, \mathrm{m} / \mathrm{v})$, and the natural abundance ${ }^{15} \mathrm{~N}$ signature of total soil $\mathrm{N}$ and root samples $(t=0)$. The other soil core remained in-situ, and was sampled after $168 \mathrm{~h}$ (i.e. after the in-situ $\mathrm{N}$ uptake experiment) and processed as before for soil water content and inorganic $\mathrm{N}$ concentration to calculate net ammonification and nitrification rates for the time of the experiment (for details see below).

On the same day that the two soil cores were installed, three cylindrical volumes of soil $(50 \mathrm{~mm}$ 
diameter, $50 \mathrm{~mm}$ deep) were injected in each collar with a solution containing three $\mathrm{N}$ species: $\mathrm{NO}_{3}{ }^{-}, \mathrm{NH}_{4}{ }^{+}$and glycine. There were three versions of this triple N-mix solution where only one of the three $\mathrm{N}$ species was ${ }^{15} \mathrm{~N}$ enriched. The solutions spiked with ${ }^{15} \mathrm{~N}^{-\mathrm{NO}_{3}}{ }^{-}$and ${ }^{15} \mathrm{~N}_{-} \mathrm{NH}_{4}{ }^{+}$were enriched to 60 atom $\%{ }^{15} \mathrm{~N}$, whereas the solution spiked with ${ }^{15} \mathrm{~N}$-glycine was enriched to 99.9 atom $\%{ }^{15} \mathrm{~N}$. Within a triple-mix solution, the concentrations of $\mathrm{N}$ for three $\mathrm{N}$ sources were: $0.71 \mathrm{mM}$ for $\mathrm{NH}_{4}{ }^{+}, 0.071 \mathrm{mM}$ for $\mathrm{NO}_{3}{ }^{-}$and $0.071 \mathrm{mM}$ for $\mathrm{N}-$ glycine. In contrast to the solutions used in the ex-situ experiments described above, these solutions did not contain ampicillin or $\mathrm{CaCl}_{2}$ as we did not want to alter soil microbial activity, or need to ensure membrane stability. We injected $5 \mathrm{~mL}$ of solution at three depths $(1,2.5$ and $4 \mathrm{~cm})$ through five injection points into each soil column ( $1 \mathrm{~mL}$ per injection point). This resulted in the application of $50 \mu \mathrm{g}$ of $\mathrm{NH}_{4}{ }^{+}-\mathrm{N}, 5 \mu \mathrm{g}$ of $\mathrm{NO}_{3}{ }^{-}-\mathrm{N}$ and $5 \mu \mathrm{g}$ glycine- $\mathrm{N}$ to the soil column, equivalent to $25.5,2.5$ and $2.5 \mathrm{mg} \mathrm{N} \mathrm{m}^{-2}$, respectively. $\mathrm{N}$ concentrations in the solution were specifically chosen so that the $\mathrm{N}$ added to the soil would only increase the existing soil $\mathrm{N}$ pools by about $10 \%$ and therefore not dramatically alter the natural concentrations of $\mathrm{NH}_{4}{ }^{+}, \mathrm{NO}_{3}{ }^{-}$and glycine in the soil. The injected soil volumes were not disturbed by inserting a core so that root uptake and rhizosphere microbial function could continue. Instead, three small plastic markers were inserted at equi-distant points along the circumference of each soil volume to record their exact locations. In total, for every land-use type there were five collars with three ${ }^{15} \mathrm{~N}-\mathrm{NO}_{3}{ }^{-}$labeled soil columns, five collars with three ${ }^{15} \mathrm{~N}_{-} \mathrm{NH}_{4}{ }^{+}$labeled soil columns and five collars with three ${ }^{15} \mathrm{~N}$-glycine labeled soil columns. From each collar, we sampled these soil volumes in sequence, at $6 \mathrm{~h}, 24 \mathrm{~h}$ and $72 \mathrm{~h}$ after ${ }^{15} \mathrm{~N}$ solution injection. Samples were kept on ice and transported to the laboratory within $2 \mathrm{~h}$. Roots were separated from soil, washed, dried and analyzed for ${ }^{15} \mathrm{~N}$ content as described above.

To calculate $\mathrm{N}$ uptake rates by these in-situ roots, we determined $\mu \mathrm{mol}{ }^{15} \mathrm{~N}$ excess in the labelled roots compared to $\mu \mathrm{mol}{ }^{15} \mathrm{~N}$ in the control roots taking the total amount of ${ }^{15} \mathrm{~N}$ tracer injected into account. In addition, we accounted for the dilution of the injected ${ }^{15} \mathrm{~N}$ tracers by the pools and fluxes of $\mathrm{NO}_{3}{ }^{+}, \mathrm{NH}_{4}^{-}$and glycine in the soil during the incubation. This method of determining $\mathrm{N}$ uptake rates allows calculating $\mathrm{N}$ uptake rates that are independent of the amount of tracer added to the ecosystem. For a detailed description of the calculations see Kahmen et al. (2006).

Soil $\mathrm{N}$ pools and fluxes

Soil $\mathrm{N}$ dynamics in the three land-use types were in detail assessed for the time that we investigated plant $\mathrm{N}$ uptake patterns. In particular, net nitrification and ammonification were measured from the difference in soil $\mathrm{NO}_{3}{ }^{-}$and $\mathrm{NH}_{4}{ }^{+}$concentrations in the soil cores sampled at the beginning of the $\mathrm{N}$ uptake experiment $(t=0)$ and from soil cores left in-situ and sampled $168 \mathrm{~h}$ after the beginning of the experiment $(t=168)$ following a method described by (Adams and Attiwill 1984). Soil cores were processed for soil water content and inorganic $\mathrm{N}$ extraction $(1: 4$, soil:1 $\mathrm{M} \mathrm{KCl}, \mathrm{m} / \mathrm{v})$. Soil $\mathrm{KCl}$ extracts were shaken for $1 \mathrm{~h}$ at $250 \mathrm{rpm}$ before being filtered (Whatman 42) and the filtrate analyzed for $\mathrm{NO}_{3}{ }^{-}$and $\mathrm{NH}_{4}{ }^{+}$concentration using a segmented continuous flow auto-analyser (Technicon TM). Net nitrification and ammonification were calculated as:

Nnet $=\frac{N_{t 1}-N_{t 0}}{t}$

where $N_{t 1}$ is the $\mathrm{NO}_{3}{ }^{-}-\mathrm{N}$ concentration $\left(\mathrm{mg} \mathrm{kg}^{-1}\right)$ at the end of the in-situ containment, $N_{t 0}$ is the $\mathrm{NO}_{3}{ }^{-}$ concentration at the start of the in-situ containment and $t$ is the number of days.

To calculate rates of gross nitrification and ammonification and to determine the amount of ${ }^{15} \mathrm{~N}$ tracer remaining in the mineral $\mathrm{N}$ soil pool over time we used the ${ }^{15} \mathrm{~N}$ labelled soil columns sampled for $\operatorname{root} \mathrm{N}$ uptake in the in-situ experiment at $t=24$ and $t=72$. After roots were removed from the soil columns, the soil was extracted with $100 \mathrm{~mL} 1 \mathrm{M} \mathrm{KCl}$ as described above and then the solution filtered directly into $500 \mathrm{~mL}$ glass jars. A $5 \mathrm{~mL}$ sub-sample of the $\mathrm{KCl}$ filtrate was removed to determine $\mathrm{NH}_{4}{ }^{+}-\mathrm{N}$ and $\mathrm{NO}_{3}{ }^{-}$$\mathrm{N}$ concentrations as described before. The remaining $\mathrm{KCl}$ filtrate $(\sim 80 \mathrm{~mL})$ received an excess addition of $\mathrm{MgO}(\sim 0.3 \mathrm{~g})$ to raise solution $\mathrm{pH}$ above 10 , so that $\mathrm{NH}_{4}{ }^{+}-\mathrm{N}$ was volatilized to $\mathrm{NH}_{3}{ }^{+}$. Immediately after adding $\mathrm{MgO}$, the lid of the glass jar was sealed. Underneath of the lid (inside the jar) was a stainlesssteel hook with an acidified $\left(2.5 \mathrm{M}, \mathrm{KHSO}_{4}\right)$ filter paper disc attached. The volatilized $\mathrm{NH}_{3}{ }^{+}$was captured on to the acidified disc through conversion back to $\mathrm{NH}_{4}{ }^{+}$over 7 days of enclosed micro-diffusion (Brooks et al. 1989). After 7 days, the jar was shortly opened, 
the filter paper removed and dried in a dessicator. Twenty-four hours later, excess Devarda's alloy $(\sim 0.20 \mathrm{~g})$ was added to reduce the remaining $\mathrm{NO}_{3}{ }^{-}$to $\mathrm{NH}_{4}{ }^{+}$, which was subsequently converted to $\mathrm{NH}_{3}{ }^{+}$and also volatilised and captured on a fresh acidified filter paper disc. The $\mathrm{NH}_{4}{ }^{+}-\mathrm{N}$ and $\mathrm{NO}_{3}{ }^{-} \mathrm{N}$ on separate, dried filter paper discs were analysed for ${ }^{15} \mathrm{~N}$ atom- $\%$ enrichment by IRMS.

Gross nitrification and ammonification were calculated using the change in $\mathrm{NO}_{3}{ }^{-}$and $\mathrm{NH}_{4}{ }^{+}$pool size and atom $\%$ enrichment between soil cores sampled 24 and $72 \mathrm{~h}$ (Murphy et al. 2003) after the injection of ${ }^{15} \mathrm{NO}_{3}{ }^{-}$ or ${ }^{15} \mathrm{NH}_{4}{ }^{+}$tracer based on ${ }^{15} \mathrm{~N}$ isotope pool dilution as:

$N_{2}^{*}=N_{1}^{*} /\left(1+\theta t / N_{1}\right)^{R / \theta}$

where $N$ is the labelled nitrate pool $\left(\mathrm{mg} \mathrm{kg}^{-1}\right), t$ is incubation time (days), $R$ is the rate of nitrification, * indicates atom- $\%$ excess ${ }^{15} \mathrm{~N}, N_{l}$ is the first time of sampling, $N_{2}$ the second and $\theta$ is the rate at which the labelled nitrate pool changed size (Barraclough 1991).

In addition to the mineral soil $\mathrm{N}$ pools and fluxes, we determined glycine concentrations in the soils of the three land-use types. The original attempt to determine soil glycine concentrations during the experiment failed, so we repeated this under comparable environmental conditions in February 2005. From each land-use type we collected 10 soil samples from $0-5 \mathrm{~cm}$ depth using a soil core ( $4.5 \mathrm{~cm}$ diameter, $0-5 \mathrm{~cm}$ depth). Glycine was extracted using $1 \mathrm{M} \mathrm{KCL}$ as described for mineral $\mathrm{N}$ above. Soil glycine concentrations were analyzed with a post-column nynhydrin-derivatization high-performance liquid chromatography-based amino acid analyzer (Model 6300; Beckman Instruments, Palo Alto, CA, USA) according to Aidar et al. (2003).

To place the soil $\mathrm{N}$ pools and fluxes measured during this experiment in the context of overall seasonal dynamics of mineral soil $\mathrm{N}$ pools in the three land-use types, we collected composite soil samples (i.e. five subsamples were combined to a single sample) from each of the three land-use types to investigate the seasonal variability in soil $\mathrm{NO}_{3}{ }^{-}$and $\mathrm{NH}_{4}{ }^{+}$pool size on a monthly basis between October 2004 and March 2005. The soil samples were sieved $(2 \mathrm{~mm})$ and subsamples taken for mineral $\mathrm{N}$ extraction (1:4, soil:1 M $\mathrm{KCl}, \mathrm{m} / \mathrm{v}$ ) and gravimetric water content as described above. The samples collected in October and November 2004 were also analyzed for total soil $\mathrm{C}$ and $\mathrm{N}$ and soil $\mathrm{pH}$. Samples were air-dried, sieved $(2 \mathrm{~mm})$ and ground
(Retsch $^{\mathrm{TM}}$, Haan, Germany) and analyzed for total C and $\mathrm{N}$ concentration by dry combustion in a $\mathrm{CHN}$ elemental analyzer (LECO ${ }^{\mathrm{TM}} \mathrm{CNH}-2000$, St. Joseph, MI, USA). Soil $\mathrm{pH}$ was measured in deionised water at a 1:5 soil:water ratio.

We determined soil bulk density in all three land-use types in order to relate the soil $\mathrm{N}$ pools and fluxes to the amount of tracer $\mathrm{N}$ that we injected into a given soil volume. Immediately after the collection of all in-situ root $\mathrm{N}$ uptake samples we collected three soil samples at $0-5 \mathrm{~cm}$ using a stainless steel soil core $(\varnothing 70 \mathrm{~mm}$, height $50 \mathrm{~mm}$ ) adjacent to each collar. Samples were oven dried at $105^{\circ}$ for $48 \mathrm{~h}$ and then weighed to determine dry soil mass per unit volume $\left(\mathrm{g} \mathrm{cm}^{-3}\right)$.

Microbial immobilization and recovery of ${ }^{15} \mathrm{~N}$ in different ecosystem $\mathrm{N}$ pools

We determined microbial and abiotic immobilization of the ${ }^{15} \mathrm{~N}$ tracers injected to the soil. After the $t=6, t=24$ and $t=72 \mathrm{~h}$ soil samples $(25 \mathrm{~g})$ had been extracted with $100 \mathrm{~mL}$ of $1 \mathrm{M} \mathrm{KCl}$ (see above), the extraction was repeated twice so that all trace of inorganic $\mathrm{N}$ had been removed from the soil residue (Recous et al. 1999). The triple- $\mathrm{KCl}$ extracted soil residue was then rinsed with $100 \mathrm{ml}$ of deionised water, centrifuged and the solution discarded and dried at $60^{\circ} \mathrm{C}$ for $48 \mathrm{~h}$. Subsamples of the dried soil residue were fine-ground on the Retsch ${ }^{\mathrm{TM}}$ ball mill and analysed for ${ }^{15} \mathrm{~N}$ atom- $\%$ enrichment using the IRMS.

To determine the recovery rates of ${ }^{15} \mathrm{~N}$ tracers in plant roots, mineral $\mathrm{N}$ and soil organic $\mathrm{N}$ we calculated $\mu \mathrm{mol}{ }^{15} \mathrm{~N}$ excess in labelled plant roots, mineral soil $\mathrm{N}$ and soil organic $\mathrm{N}$ as compared to $\mu \mathrm{mol}{ }^{15} \mathrm{~N}$ in the unlabeled controls $(t=0)$ and expressed the recovery rates as percent of the ${ }^{15} \mathrm{~N}$ tracer originally injected into the soil.

\section{Statistics}

We used one-way ANOVAs with Turkey's post-hoc tests to determine separately for the individual land-use types a) statistical differences for the uptake of a given $\mathrm{N}$ species across different 'N-uptake methods', and b) statistical differences among $\mathrm{NO}_{3}{ }^{+}, \mathrm{NH}_{4}{ }^{-}$and glycine uptake for a given ' $\mathrm{N}$ uptake method'. In both tests, we used $\mathrm{N}$ uptake rate of a given $\mathrm{N}$ species as dependent variable and either ' $\mathrm{N}$ uptake method' (a) or ' $\mathrm{N}$ species' (b) as factor. 


\section{Results}

$\mathrm{NO}_{3}{ }^{-}$and glycine concentrations were at least one order of magnitude smaller than $\mathrm{NH}_{4}^{+}$concentrations across the three land-use types at the time we assessed root $\mathrm{N}$ uptake patterns (Fig. 1). Similarly, gross and net ammonification were more than one order of magnitude higher than gross and net nitrification in all three land-use types (Table 1). Gross and net ammonification was highest in the pasture and lowest in the E. globulus plantation. Likewise, gross and net nitrification was extremely low in the E. globulus plantation and only slightly higher in the pasture and $P$. radiata plantation. These patterns are consistent with the seasonal trend that we observed for mineral soil $\mathrm{N}$ pools in the three land-use types. Although there was some seasonal variability over the growing season, $\mathrm{NH}_{4}{ }^{+}$dominated the plant available mineral soil $\mathrm{N}$ pool throughout the year in all land uses (Fig. 2). Overall, this suggests that $\mathrm{NH}_{4}{ }^{+}$is the dominant form of plant available $\mathrm{N}$ in these ecosystems.

Soil $\mathrm{pH}$ ranged from 4.33 in the $P$. radiata plantation to 4.52 in the E. globulus plantation and 4.89 in the pasture. Soil $C$ was significantly higher in the $P$. radiata and E. globulus plantations $(5.76 \%$ and $5.03 \%$, respectively) as compared to the pasture (4.21\%). In contrast, soil $\mathrm{N}$ was comparable across all three land-use types, ranging from $0.42 \%$ in the P. radiata plantation to $0.48 \%$ in the E. globulus plantation (Table 1).

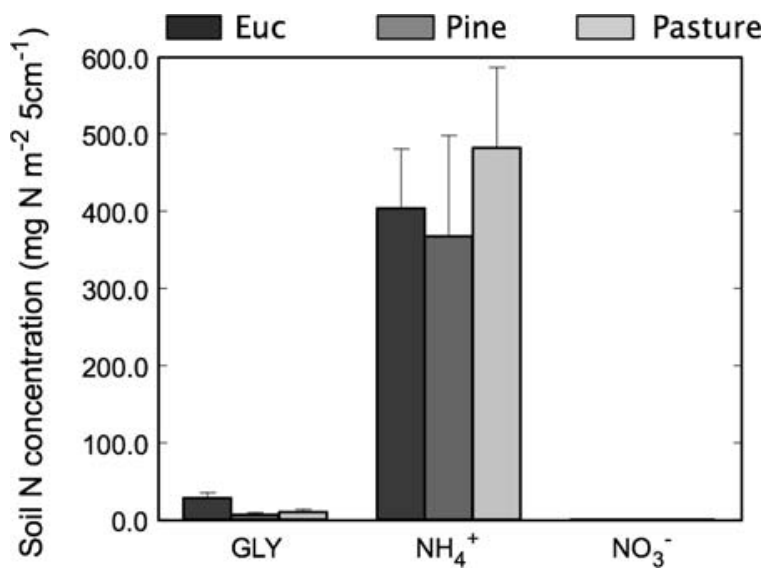

Fig. 1 Concentrations of glycine, ammonium and nitrate in the upper $5 \mathrm{~cm}$ of the mineral soils of the three land-use types. $\mathrm{NH}_{4}{ }^{+}$and $\mathrm{NO}_{3}{ }^{-}$were sampled at the time of the experiment while samples for glycine were collected at the same time of the following year
When uptake of different $\mathrm{N}$ species was tested using excavated attached roots, $P$. radiata and E. globulus relied exclusively on $\mathrm{NH}_{4}^{+}$and glycine, and showed only marginal $\mathrm{NO}_{3}{ }^{-}$uptake (Fig. 3a). Laboratory incubations of excavated and detached roots revealed that roots from the pasture took up all three $\mathrm{N}$ species with a preference for $\mathrm{NH}_{4}^{+}$, while $P$. radiata and E. globulus again only took up $\mathrm{NH}_{4}{ }^{+}$and glycine, not $\mathrm{NO}_{3}{ }^{-}$(Fig. 3b). In both ex-situ $\mathrm{N}$ uptake experiments, glycine was a substantial $\mathrm{N}$ source for plant roots from all three land-use types. In contrast, when $\mathrm{N}$ uptake directly from the soil was tested in-situ with in intact roots, $\mathrm{NH}_{4}^{+}$was the exclusive $\mathrm{N}$ source for plants from all three land-use types, while neither $\mathrm{NO}_{3}{ }^{-}$nor glycine contributed to a plant's $\mathrm{N}$ uptake in significant amounts in any of the three land-use types (Fig. 3c).

Root uptake rates of $\mathrm{NO}_{3}{ }^{-}, \mathrm{NH}_{4}{ }^{+}$and glycine were in the same order of magnitude in all three $\mathrm{N}$ uptake experiments, independent of method (Fig. 3). However, we found marked differences with regard to the relative amount of different $\mathrm{N}$ species acquired by plant roots depending on the method used to measure $\mathrm{N}$ uptake (Fig. 4). When $\mathrm{N}$ uptake was measured exsitu, using either attached or excised roots, glycine contributed significantly to overall $\mathrm{N}$ uptake, ranging from $63.2 \%$ for attached $P$. radiata roots to $20.8 \%$ for excised E. globulus roots. In contrast, when $\mathrm{N}$ uptake from the soil was measured for roots in-situ $\mathrm{NH}_{4}{ }^{+}$ dominated the $\mathrm{N}$ taken up, while glycine uptake declined to $4.7 \%$ for E. globulus, $2.7 \%$ for P. radiata and $1.7 \%$ for pasture roots of overall $\mathrm{N}$ uptake (Fig. 4). Each of the three methods used to measure $\mathrm{N}$ uptake by plant roots influenced the perceived plant $\mathrm{N}$ uptake pattern, a finding that was consistent across all three land-use types: organic $\mathrm{N}$ uptake declined at the expense of $\mathrm{NH}_{4}^{+}$uptake from ex-situ attached roots, to ex-situ excised roots and finally to in-situ direct $\mathrm{N}$ uptake from the soil (Fig. 4).

Total recovery of the ${ }^{15} \mathrm{~N}$ label injected into the soil of the three land-use types ranged from between 45.7\% (P. radiata, ${ }^{15} \mathrm{NO}_{3}{ }^{-}$treatment) and $119.1 \%$ (pasture, ${ }^{15} \mathrm{NO}_{3}{ }^{-}$treatment) with mean recovery rates of $65.8 \%, 85.9 \%$ and $59.2 \%$ for the E. globulus, pasture and $P$. radiata land-use type, respectively. ${ }^{15} \mathrm{~N}$ tracers were recovered in all soil $\mathrm{N}$ pools except for the $\mathrm{NO}_{3}{ }^{-}$pool, which was very low to nondetectable (Fig. 5). Of the recovered ${ }^{15} \mathrm{~N}$ label, the largest proportion was recovered in the insoluble organic N soil pool (Fig. 5). Substantial amounts of 
Table 1 Soil edaphic properties in the three land-use types. ${\mathrm{Net} \mathrm{NO}_{3}}^{-}$(flux) and $\mathrm{NH}_{4}^{+}$(flux) refer to daily net mineralization rates. Gross $\mathrm{NO}_{3}{ }^{-}$(flux) and $\mathrm{NH}_{4}^{+}$(flux) refer to daily gross mineralization rates from ${ }^{15} \mathrm{~N}$ isotope pool dilution between 24 and $72 \mathrm{~h}$

\begin{tabular}{|c|c|c|c|c|c|}
\hline & $\mathrm{n}$ & Unit & E. globulus & P. radiata & Pasture \\
\hline Net $\mathrm{NO}_{3}^{-}{ }_{\text {(flux) }}^{-}$ & 10 & $\mu \mathrm{g}-\mathrm{N} \mathrm{g}_{\text {soil }}{ }^{-1} \mathrm{~d}^{-1}$ & $0.00( \pm 0.02)$ & $0.23( \pm 0.19)$ & $0.08( \pm 0.08)$ \\
\hline Gross $\mathrm{NO}_{3}^{-}$(flux) & 5 & $\mu \mathrm{g}-\mathrm{N} \mathrm{g}_{\text {soil }}{ }^{-1} \mathrm{~d}^{-1}$ & $0.04( \pm 0.01)$ & $0.39( \pm 0.03)$ & $0.17( \pm 0.04)$ \\
\hline Net $\mathrm{NH}_{4}^{+}$(flux) & 10 & $\mu \mathrm{g}-\mathrm{N} \mathrm{g}_{\text {soil }}{ }^{-1} \mathrm{~d}^{-1}$ & $0.32( \pm 0.52)$ & $0.41( \pm 1.15)$ & $0.60( \pm 0.78)$ \\
\hline Gross $\mathrm{NH}_{4}^{+}$(flux) & 5 & $\mu \mathrm{g}-\mathrm{N} \mathrm{g}_{\text {soil }}{ }^{-1} \mathrm{~d}^{-1}$ & $1.81( \pm 0.38)$ & $3.36( \pm 0.19)$ & $3.69( \pm 0.24)$ \\
\hline Soil bulk density & 5 & $\mathrm{~kg}_{\text {soil }} \mathrm{m}^{-2} 5 \mathrm{~cm}^{-1}$ & $60.89( \pm 34.5)$ & $70.21( \pm 29.7)$ & $87.99( \pm 35.9)$ \\
\hline Soil C & $2^{\mathrm{a}}$ & $\%$ & $5.76( \pm 0.27)$ & $5.03( \pm 0.41)$ & $4.21( \pm 0.32)$ \\
\hline Soil N & $2^{\mathrm{a}}$ & $\%$ & $0.48( \pm 0.09)$ & $0.42( \pm 0.06)$ & $0.46( \pm 0.14)$ \\
\hline Soil pH & 3 & log scale & $4.52( \pm 0.20)$ & $4.33( \pm 0.06)$ & $4.89( \pm 0.04)$ \\
\hline
\end{tabular}

a $=$ composite $(n=5)$ soil sample $(0-10 \mathrm{~cm})$

Soil bulk density was determined for the upper $5 \mathrm{~cm}$ of mineral soil. Standard deviations from the mean are presented in parenthesis.

${ }^{15} \mathrm{~N}$ tracer were, however, also recovered from the mineral $\mathrm{N}$ pool (i.e. the soil $\mathrm{NH}_{4}{ }^{+}$pool). The recovery rates in the mineral $\mathrm{N}$ pool in all three land-use types declined over time at the expense of the insoluble organic $\mathrm{N}$ pool, which increased over time. In contrast to the insoluble organic $\mathrm{N}$ pool and the mineral $\mathrm{N}$ pool, the proportion of label recovered in the roots was small, ranging from $1.2-3.0 \%$ in E. globulus roots, $3.6-12.1 \%$ in pasture roots and $1.0-3.7 \%$ in P. radiata roots (Fig. 5). For roots, we were not able to detect an increase or decrease in recovered ${ }^{15} \mathrm{~N}$ label over time.

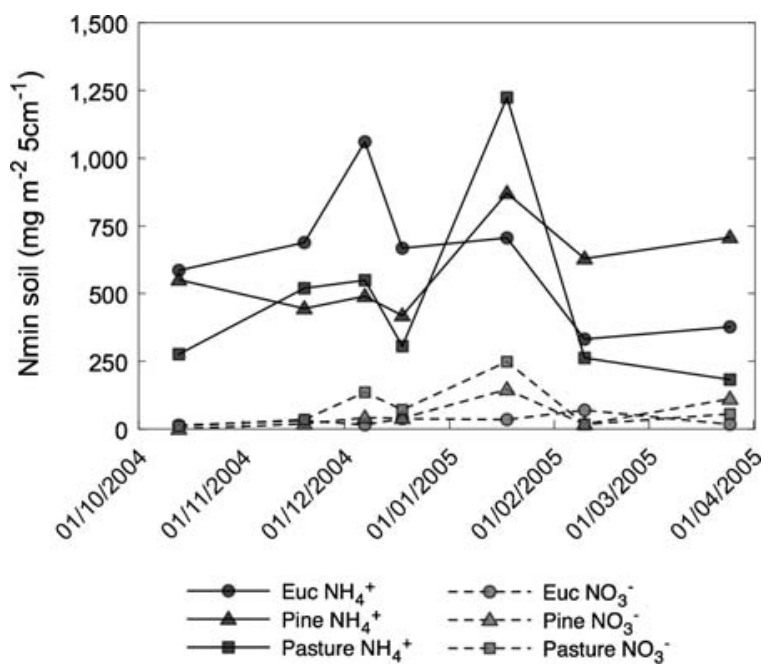

Fig. 2 Seasonal variation of extractable $\mathrm{NO}_{3}{ }^{-}$and $\mathrm{NH}_{4}{ }^{+}$in the upper $5 \mathrm{~cm}$ of the mineral soils of the three investigated landuse types

\section{Discussion}

Ammonium and glycine were the dominant forms of root $\mathrm{N}$ uptake in both, the excavated attached roots and the excavated detached roots experiment (Fig. 4). The high levels of glycine uptake that we detected using exsitu $\mathrm{N}$ uptake methods show the potential of plant species from all three land-use types to use LMW organic $\mathrm{N}$ as an $\mathrm{N}$ source. Our findings are consistent with a broad range of other studies that have found LMW organic N uptake from solutions (FalkengrenGrerup et al. 2000; Finzi and Berthrong 2005; Kielland 1994; Raab et al. 1999; Schmidt and Stewart 1999; Warren and Adams 2007). Our study therefore supports the suggestion that the potential for LMW organic N uptake by plant roots is a widespread functional trait of plants from different ecosystems around the globe.

The uptake rates for $\mathrm{NO}_{3}{ }^{-}$from the solutions were minimal for E. globulus and $P$. radiata in both ex-situ experiments compared to $\mathrm{NH}_{4}^{+}$and glycine uptake. Only the pasture roots showed some $\mathrm{NO}_{3}{ }^{-}$uptake (Figs. 3 and 4). Low levels of $\mathrm{NO}_{3}{ }^{-}$uptake reflect the small $\mathrm{NO}_{3}{ }^{-}$pools and fluxes that we measured in the soils of all three land-use types (Figs. 1 and 2, Table 1) and could therefore be the result of root adaptation to high $\mathrm{NH}_{4}{ }^{+}$and low $\mathrm{NO}_{3}{ }^{-}$concentrations in these soils. Also, the presence of $\mathrm{NH}_{4}{ }^{+}$and amino acids has been shown to inhibit root uptake of $\mathrm{NO}_{3}{ }^{-}$from solution, which could also explain the low levels of $\mathrm{NO}_{3}{ }^{-}$uptake in our ex-situ experiments (Haynes and Goh 1978; Thornton and Robinson 2005).

Both ex-situ methods that we used to determine the potential of plants for glycine uptake have several 
a

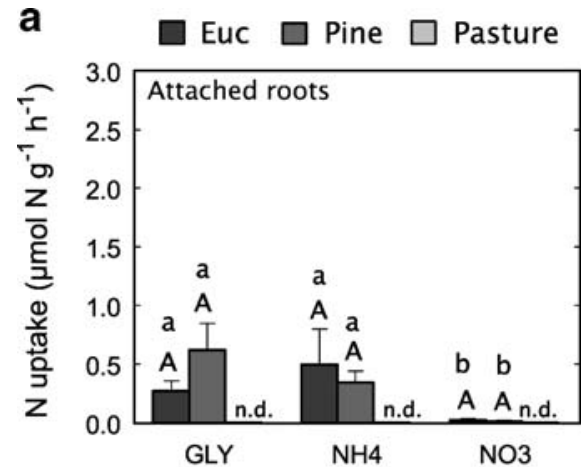

b
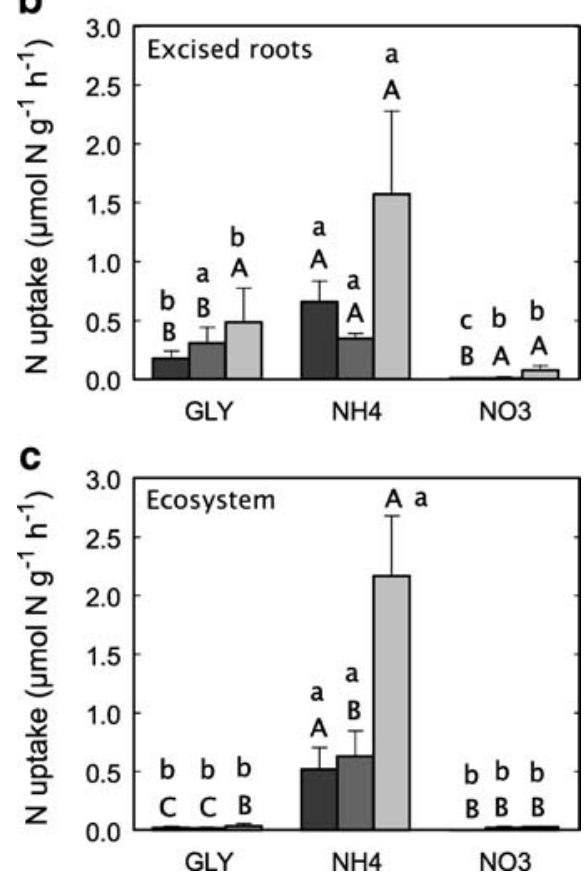

Fig. 3 Uptake rates for $\mathrm{NO}_{3}{ }^{-}, \mathrm{NH}_{4}^{+}$and glycine for $E$. globulus, $P$. radiata and pasture plant roots determined with excavated but intact roots (a), excavated and detached roots (b) and intact rhizosphere roots by injecting ${ }^{15} \mathrm{~N}$ labeled solutions into the soil (c). The attached root method was not tested in the grassland (n.d.). We used one-way ANOVAs with Turkey's post-hoc tests to determine separately for the individual landuse types a) statistical differences for the uptake of a given $\mathrm{N}$ species across different 'N-uptake methods' (capital letters), and b) statistical differences among $\mathrm{NO}_{3}{ }^{+}, \mathrm{NH}_{4}{ }^{-}$and glycine uptake for a given ' $\mathrm{N}$ uptake method' (lower case letters). Error bars represent one standard deviation from the mean

disadvantages that can impact the $\mathrm{N}$ uptake rates of roots (Lucash et al. 2007). For excised roots it has been argued that $2 \mathrm{~h}$ after a root has been cut, soluble sugar concentrations and metabolic activity in that root sharply decline which affects the capacity for active uptake of compounds and may lead to an underesti- mation of root N uptake capacity (Farrar 1985). Similarly, it has been estimated that measuring nutrient uptake on roots that remain attached to a tree could underestimate $\mathrm{N}$ uptake rates by $10 \%$ as some of the $\mathrm{N}$ is transported away from the root towards the trunk of the tree (Hawkins et al. 2005; Warren and Adams 2007). It is noteworthy that the general $\mathrm{N}$ uptake patterns we obtained from both ex-situ experiments are similar, given the uncertainties regarding both methods in determining $\mathrm{N}$ uptake from solution and despite the higher relative $\mathrm{NH}_{4}^{+}$uptake in excised roots as compared to attached roots. The magnitude of absolute $\mathrm{NH}_{4}^{+}$and glycine uptake, as well as the general patterns with respect to $\mathrm{N}$ preferences of the different species, is comparable in both ex-situ methods; both $E$. globulus and $P$. radiata show a clear overall preference for $\mathrm{NH}_{4}^{+}$and glycine uptake, but neither tree species takes up much $\mathrm{NO}_{3}{ }^{-}$(Figs. 3 and 4).

Measuring the uptake of $\mathrm{N}$ from nutrient solutions by roots ex-situ from their soil environment provides important information on $\mathrm{N}$ uptake kinetics or the potential of plants to acquire LMW organic N. However, these 'root ex-situ in solution' studies reveal relatively little information on the ecological importance of LMW organic N uptake by plant roots (Jones et al. 2005; Näsholm et al. 1998; Owen and Jones 2001). We

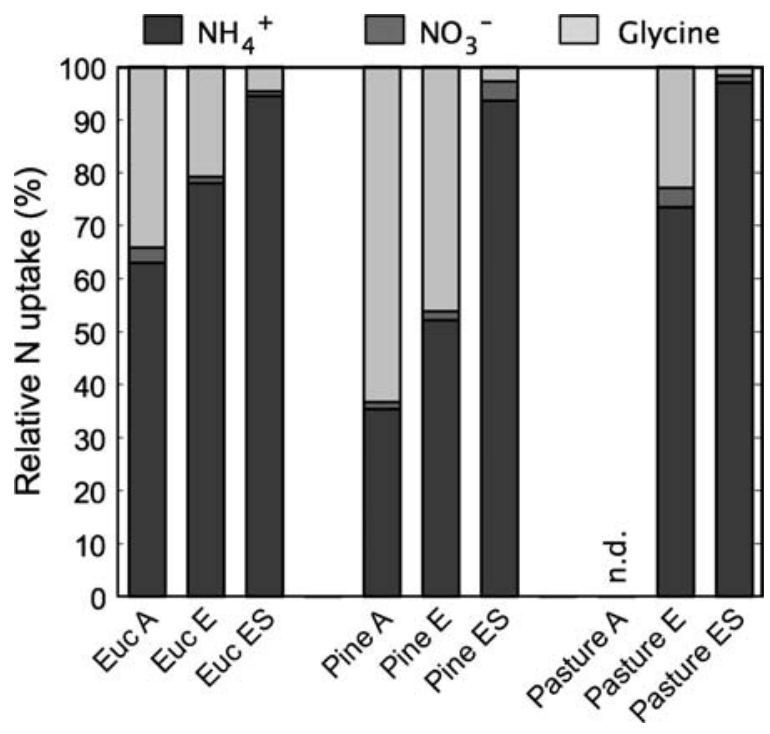

Fig. 4 Uptake rates of $\mathrm{NO}_{3}{ }^{-}, \mathrm{NH}_{4}{ }^{+}$and glycine in relation to total $\mathrm{N}$ uptake in comparison of three different methods determining $\mathrm{N}$ uptake of E. globulus, $P$. radiata and grassland roots. A: excavated, attached roots, E: excavated and detached roots and ES: recovery of a ${ }^{15} \mathrm{~N}$ tracer from the soil. The attached root method was not tested in the grassland (n.d.) 

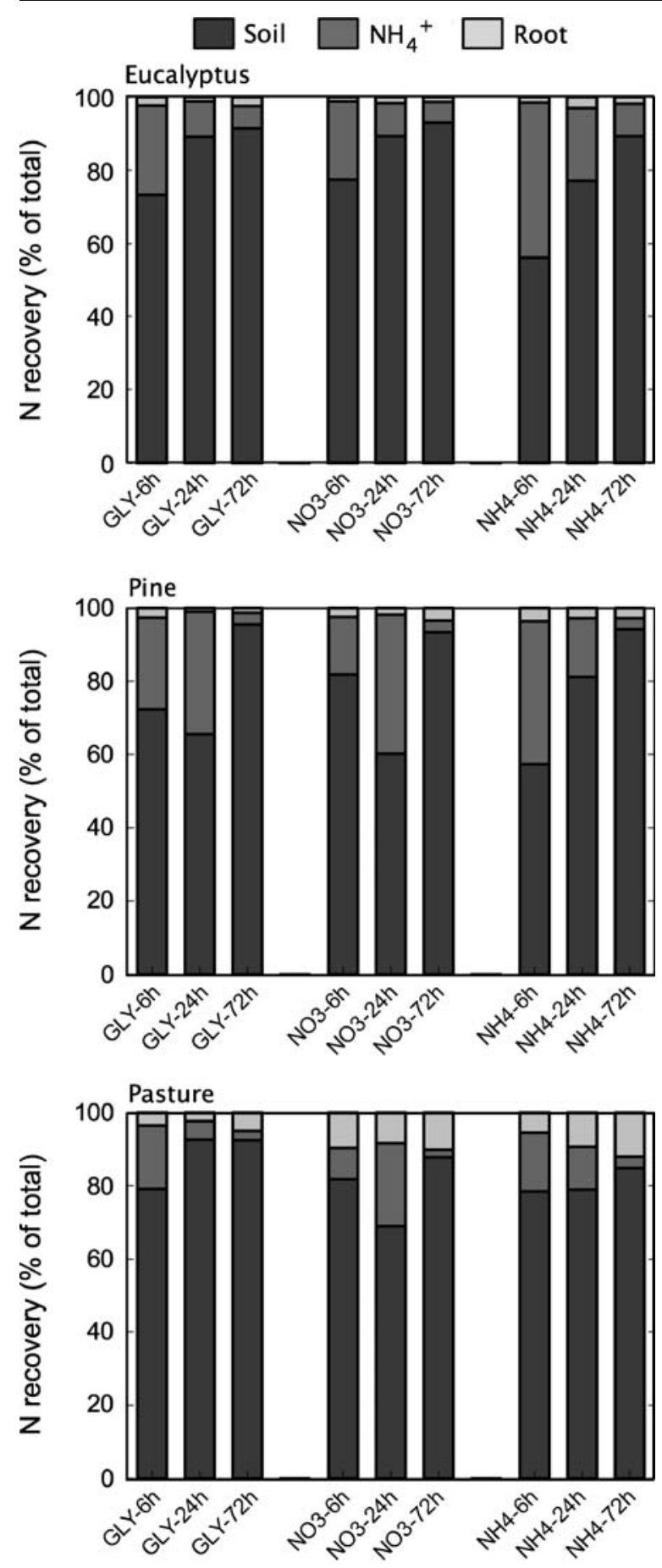

Fig. 5 Recovery rates (\% of total tracer recovered in a treatment) of ${ }^{15} \mathrm{~N}$ in different compartments (roots, Nmin, soil organicN/microbialN) the in-situ experiment for all three landuse types. Each bar indicates a separate treatment (glycine, $\left.\mathrm{NO}_{3}{ }^{-}, \mathrm{NH}_{4}{ }^{+}\right)$at the three points in time $(6 \mathrm{~h}, 24 \mathrm{~h}, 72 \mathrm{~h}) .>90 \%$ of the recovered tracer was found in the organic $\mathrm{N} /$ microbial compartment, independent of treatment and time

therefore, determined in-situ $\mathrm{N}$ uptake patterns of intact plant roots in the three land-use types. Interestingly, glycine uptake in the in-situ experiment was extremely small, contributing between $2 \%$ and $5 \%$ to the overall $\mathrm{N}$ uptake of E. globulus, P. radiata or pasture grasses. In contrast, $\mathrm{NH}_{4}{ }^{+}$was the dominant $\mathrm{N}$ source for plant roots contributing more than $93.5 \%$ to overall $\mathrm{N}$ uptake in all land-use types (Fig. 4). While our ex-situ experiments have clearly shown the potential for the plants to acquire LMW organic $\mathrm{N}$ in the form of glycine, the small uptake rates measured in-situ suggest that the actual ecological relevance of LMW organic $\mathrm{N}$ in the form of glycine may be limited in these three ecosystems - at least during the time of this experiment.

Small concentrations of glycine in the soil in combination with microbial competition and abiotic immobilization of LMW organic and mineral N could explain why plants that have a high potential for LMW organic $\mathrm{N}$ uptake show low in-situ uptake rates for glycine (Hodge et al. 2000; Jones et al. 2004; Kaye and Hart 1997). It has been shown for a cold temperate forests, for example, that more than $90 \%$ of ${ }^{15} \mathrm{~N}$ labeled glycine was recovered in either $\mathrm{NH}_{4}{ }^{+}$or in the soil microbial biomass only $15 \mathrm{~min}$ after it was injected into the soil (Finzi and Berthrong 2005). Similarly, other studies have shown that microbes compete very effectively with plants for LMW organic $\mathrm{N}$ in temperate grassland ecosystems (Bardgett et al. 2003; Harrison et al. 2007) or subarctic tundra (Sorensen et al. 2008). In agreement with these previous studies, we recovered more than $70 \%$ of the ${ }^{15} \mathrm{~N}$ label in the insoluble soil organic $\mathrm{N}$ pool within $6 \mathrm{~h}$ of injection in all three land-use types and for all three labeled $\mathrm{N}$ species (Fig. 5). In contrast, we recovered only between 1.2 and $9.4 \%$ of ${ }^{15} \mathrm{~N}$ in plant roots $6 \mathrm{~h}$ after injection, suggesting that glycine, like mineral $\mathrm{N}$, in these three ecosystems is rapidly immobilized by microbial uptake or abiotic processes, leaving only a small proportion available for root uptake. It is interesting to note, however, that the relative rates of immobilization were largely independent of $\mathrm{N}$ species as was the fraction of a given $\mathrm{N}$ species that was available for root uptake (Fig. 5). This suggests that not microbial preference for a given $\mathrm{N}$ species but the small concentrations of glycine and $\mathrm{NO}_{3}{ }^{-}$that we found in the soil as compared to $\mathrm{NH}_{4}{ }^{+}$, explains why glycine and $\mathrm{NO}_{3}{ }^{-}$ contributed little to the overall $\mathrm{N}$ uptake of plants in the three ecosystems. 
Our study provides evidence that $\mathrm{N}$ uptake patterns for mineral $\mathrm{N}$ and glycine largely reflect the availability of the different $\mathrm{N}$ species in the soil when tested with intact roots in-situ (Figs. 1 and 3). This suggests that in-situ $\mathrm{N}$-uptake studies need to be carefully designed in order not to bias the observed $\mathrm{N}$ uptake patterns. In our experiment, we were particularly cautious not to alter the relative abundances of the different $\mathrm{N}$ species in the soil by injecting $\mathrm{NH}_{4}^{+}$, $\mathrm{NO}_{3}{ }^{-}$and glycine at concentrations that ranged roughly around $10 \%$ of the naturally occurring concentrations. In addition, we applied a novel method that allowed us to estimate the absolute uptake rates of different $\mathrm{N}$ species by accounting for the dilution of the tracer through net $\mathrm{N}$ mineralization fluxes as well as existing pools of the relevant $\mathrm{N}$ species (Kahmen et al. 2006; Kahmen et al. 2008). As such, the calculated $\mathrm{N}$ uptake rates are independent of the amount of tracer applied. To do so, we assessed concentrations of $\mathrm{NH}_{4}{ }^{+}, \mathrm{NO}_{3}{ }^{-}$and glycine during the experiment as well as the net $\mathrm{NH}_{4}{ }^{+}$and $\mathrm{NO}_{3}{ }^{-}$fluxes. Since it was not possible to determine the net glycine fluxes in this experiment, we made the assumption that net glycine fluxes are in the same order of magnitude as net $\mathrm{NH}_{4}{ }^{+}$fluxes. While this introduces uncertainty to our calculations of in-situ glycine $\mathrm{N}$ uptake, the net fluxes that we determined in this study were small compared to the respective pools (Fig. 1, Table 1). As a result, the error that our assumption introduces to our estimates of glycine uptake is unlikely to affect the overall patterns that we detected in this study. We acknowledge that methodological difficulties can introduce error to our estimates of $\mathrm{N}$ uptake, in particular determining the exact flux rates of $\mathrm{NH}_{4}{ }^{+}, \mathrm{NO}_{3}{ }^{-}$and glycine (Näsholm et al. 2001). However, the method we used provides us with more realistic estimates of $\mathrm{N}$ uptake rates than the typically reported ${ }^{15} \mathrm{~N}$ recovery rates that are biased by the amount of tracer added to the ecosystem, and that are affected by the dilution of the tracer in the soil (Jones et al. 2005; Näsholm et al. 2001; Nordin et al. 2004).

In the study presented here we have used glycine as a proxy for root uptake of LMW organic $\mathrm{N}$ compounds. Glycine is, however, only one out of a large number of LMW organic N compounds that can be taken up by plants (Weigelt et al. 2005). Our study might therefore underestimate the overall contribution of LMW organic $\mathrm{N}$ compounds to plant $\mathrm{N}$ uptake in the three land-use types. However, the low abundance of glycine in the soil, the high net mineralization rates and the high rates of microbial immobilization observed provide little evidence that other LMW organic $\mathrm{N}$ compounds would be substantially more abundant in these soils and contribute differently to overall plant $\mathrm{N}$ uptake in the investigated ecosystems.

Uptake of intact LMW organic $\mathrm{N}$ directly from the soil is often studied using ${ }^{13} \mathrm{C}$ and ${ }^{15} \mathrm{~N}$ labeled compounds (Näsholm et al. 1998). In our study, we used glycine that was only ${ }^{15} \mathrm{~N}$ labeled that does not allow to distinguish if the ${ }^{15} \mathrm{~N}$ has been taken up as intact organic compound or has been mineralized prior to uptake. However, this does not confound the findings of our study since organic $\mathrm{N}$ is of limited relevance for overall plant $\mathrm{N}$ uptake in all three investigated ecosystems. Further, given the large unlabeled $\mathrm{C}$ pool in the roots of plants compared with the small amount of ${ }^{13} \mathrm{C}$ that would have been taken up in this study from ${ }^{13} \mathrm{C}$ and ${ }^{15} \mathrm{~N}$ labeled glycine, we question if significant amounts of the ${ }^{13} \mathrm{C}$ tracer could have been detected at all in this study (von Felten et al. 2008).

At first glance the data we present seems to contradict previous studies that have shown LMW organic $\mathrm{N}$ contributes to the overall $\mathrm{N}$ uptake of plants (McKane et al. 2002; Näsholm et al. 1998; Näsholm et al. 2001; Nordin et al. 2004; Persson et al. 2003; Xu et al. 2008). However, the glycine uptake patterns we report for these three Australian ecosystems fit well into Schimel and Bennett's (2004) general conceptual model of LMW organic $\mathrm{N}$ uptake across ecosystems with varying $\mathrm{N}$ availability and microbial competition. While previous studies have reported LMW organic N uptake by plants either from arctic, alpine or boreal ecosystems where $\mathrm{N}$ mineralization rates and levels of plant available $\mathrm{N}$ are low or from $\mathrm{N}$ saturated agricultural ecosystems, where microbial competition for $\mathrm{N}$ is limited, the three landuse types we investigated in this study showed intermediate levels of $\mathrm{N}$ availability at the time of this experiment: ammonification and $\mathrm{NH}_{4}{ }^{+}$pools in the soil were high compared to nitrification and $\mathrm{NO}_{3}{ }^{-}$and glycine pools (Table 1, Fig. 2). Yet microbial competition and abiotic immobilization for LMW organic $\mathrm{N}$ as well as mineral $\mathrm{N}$ was still high as indicated by the high immobilization rates after in-situ application of tracers in all land-uses (Fig. 5). In accordance with Schimel and Bennett (2004) our study therefore suggests that under these conditions of intermediate $\mathrm{N}$ availability LMW organic $\mathrm{N}$ is of limited ecological relevance to the overall $\mathrm{N}$ nutrition of the dominant plant species. 
Acknowledgements We would like to thank Edith Huber for assistance in the field and for help with sample preparation in the laboratory, Matt Lee and Najib Ahmady for assistance with laboratory analyses. Nick Williams kindly assisted with identification of pasture plant species. Pamela Templer and two anonymous referees gave valuable comments on an earlier version of the manuscript. The Department of Sustainability and Environment of Victoria provided funding for this experiment. AK was financed by an Erwin-Schroedinger Fellowship of the Austrian Science Fund (FWF) and by a Marie-Curie Outgoing International fellowship of the European Union.

Open Access This article is distributed under the terms of the Creative Commons Attribution Noncommercial License which permits any noncommercial use, distribution, and reproduction in any medium, provided the original author(s) and source are credited.

\section{References}

Adams MA, Attiwill PM (1984) Patterns of nitrogen mineralization in 23 year old pine forest following nitrogen fertilizing. For Ecol Manage 7:241-248. doi:10.1016/ 0378-1127(84) 90001-X

Aidar MPM, Schmidt S, Moss G, Stewart GR, Joly CA (2003) Nitrogen use strategies of neotropical rainforest trees in threatened Atlantic Forest. Plant Cell Environ 26:389-399. doi:10.1046/j.1365-3040.2003.00970.x

Bardgett RD, Streeter TC, Bol R (2003) Soil microbes compete effectively with plants for organic-nitrogen inputs to temperate grasslands. Ecology 84:1277-1287. doi:10.1890/ 0012-9658(2003) 084[1277:SMCEWP]2.0.CO;2

Barraclough D (1991) The use of mean pool abundances to interpret N-15 tracer experiments. 1. Theory. Plant Soil 131:89-96

Brooks PD, Stark JM, McInteer BB, Preston T (1989) Diffusion method to prepare soil extracts for automated ${ }^{15} \mathrm{~N}$ analysis. Soil Sci Soc Am J 53:1707-1711

Chapin FS, Moilanen L, Kielland K (1993) Preferential use of organic nitrogen for growth by a nonmycorrhizal arctic sedge. Nature 361:150-153. doi:10.1038/361150a0

Clemmensen KE, Sorensen PL, Michelsen A, Jonasson S, Strom L (2008) Site-dependent N uptake from N-form mixtures by arctic plants, soil microbes and ectomycorrhizal fungi. Oecologia 155:771-783. doi:10.1007/s00442-0080962-9

Falkengren-Grerup U, Mansson KF, Olsson MO (2000) Uptake capacity of amino acids by ten grasses and forbs in relation to soil acidity and nitrogen availability. Environ Exp Bot 44:207-219. doi:10.1016/S0098-8472(00) 00068-X

Farrar JF (1985) Fluxes of carbon in roots of barley plants. New Phytol 99:57-69. doi:10.1111/j.1469-8137.1985.tb03636.x

Finzi AC, Berthrong ST (2005) The uptake of amino acids by microbes and trees in three cold-temperate forests. Ecology 86:3345-3353. doi:10.1890/04-1460

Harrison KA, Bol R, Bardgett RD (2007) Preferences for different nitrogen forms by coexisting plant species and soil microbes. Ecology 88:989-999. doi:10.1890/06-1018

Hawkins HJ, Wolf G, Stock WD (2005) Cluster roots of Leucadendron laureolum (Proteaceae) and Lupinus albus
(Fabaceae) take up glycine intact: an adaptive strategy to low mineral nitrogen in soils? Ann Bot (Lond) 96:12751282. doi:10.1093/aob/mci279

Haynes RJ, Goh KM (1978) Ammonium and nitrate nutrition of plants. Biol Rev Camb Philos Soc 53:465-510. doi:10.1111/ j.1469-185X.1978.tb00862.x

Hodge A, Robinson D, Fitter A (2000) Are microorganisms more effective than plants at competing for nitrogen? Trends Plant Sci 5:304-308. doi:10.1016/S1360-1385(00) 01656-3

Jackson LE, Schimel JP, Firestone MK (1989) Short-term partitioning of ammonium and nitrate between plants and microbes in an annual grassland. Soil Biol Biochem 21:409-415. doi:10.1016/0038-0717(89) 90152-1

Jones DL, Shannon D, Murphy DV, Farrar J (2004) Role of dissolved organic nitrogen (DON) in soil $\mathrm{N}$ cycling in grassland soils. Soil Biol Biochem 36:749-756. doi:10.1016/ j.soilbio.2004.01.003

Jones DL, Healey JR, Willett VB, Farrar JF, Hodge A (2005) Dissolved organic nitrogen uptake by plants - an important $\mathrm{N}$ uptake pathway? Soil Biol Biochem 37:413-423. doi:10. 1016/j.soilbio.2004.08.008

Kahmen A, Renker C, Unsicker S, Buchmann N (2006) Niche complementarity for nitrogen: an explanation for the biodiversity and ecosystem functioning relationship? Ecology 87:1244-1255. doi:10.1890/0012-9658(2006) 87[1244: NCFNAE]2.0.CO;2

Kahmen A, Wanek W, Buchmann N (2008) Foliar $\delta^{15}$ Nvalues characterize soil $\mathrm{N}$ cycling and reflect nitrate or ammonium preference of plants along a temperate grassland gradient. Oecologia 156:861-870. doi:10.1007/s00442008-1028-8

Kaye JP, Hart SC (1997) Competition for nitrogen between plants and soil microorganisms. Trends Ecol Evol 12:139143. doi:10.1016/S0169-5347(97) 01001-X

Kielland K (1994) Amino acid absorption by arctic plants Implications for plant nutrition and nitrogen cycling. Ecology 75:2373-2383. doi:10.2307/1940891

Kinzel H (1982) Pflanzen Ökologie und Mineralstoffwechsel. Eugen Ulmer Verlag, Stuttgart

Lipson DA, Monson RK (1998) Plant-microbe competition for soil amino acids in the alpine tundra: effects of freeze-thaw and dry-rewet events. Oecologia 113:406-414. doi:10.1007/ s004420050393

Lipson DA, Raab TK, Schmidt SK, Monson RK (1999) Variation in competitive abilities of plants and microbes for specific amino acids. Biol Fertil Soils 29:257-261. doi:10.1007/ s003740050550

Lucash MS, Eissenstat DM, Joslin JD, McFarlane KJ, Yanai RD (2007) Estimating nutrient uptake by mature tree roots under field conditions: challenges and opportunities. TreesStructure Funct 21:593-603

McKane RB, Johnson LC, Shaver GR, Nadelhoffer KJ, Rastetter EB, Fry B, Giblin AE, Kielland K, Kwiatkowski BL, Laundre JA, Murray G (2002) Resource-based niches provide a basis for plant species diversity and dominance in arctic tundra. Nature 415:68-71. doi:10.1038/415068a

Miller AE, Bowman WD, Suding KN (2007) Plant uptake of inorganc and organic nitrogen: neighbor identity matters. Ecology 88:1832-1840. doi:10.1890/06-0946.1

Murphy DV, Recous S, Stockdale EA, Fillery IRP, Jensen LS, Hatch DJ, Goulding KWT (2003) Gross nitrogen fluxes in 
soil: theory, measurement and application of ${ }^{15} \mathrm{~N}$ pool dilution techniques. Adv Agron 79:69-118. Academic Press Inc, San Diego. doi:10.1016/S0065-2113(02)79002-0

Näsholm T, Ekblad A, Nordin A, Giesler R, Hogberg M, Högberg P (1998) Boreal forest plants take up organic nitrogen. Nature 392:914-916. doi:10.1038/31921

Näsholm T, Huss-Danell K, Högberg P (2000) Uptake of organic nitrogen in the field by four agriculturally important plant species. Ecology 81:1155-1161

Näsholm T, Huss-Danell K, Högberg P (2001) Uptake of glycine by field grown wheat. New Phytol 150:59-63. doi:10.1046/j.1469-8137.2001.00072.x

Nordin A, Högberg P, Nasholm T (2001) Soil nitrogen form and plant nitrogen uptake along a boreal forest productivity gradient. Oecologia 129:125-132. doi:10.1007/s0044 20100698

Nordin A, Schmidt IK, Shaver GR (2004) Nitrogen uptake by arctic soil microbes and plants in relation to soil nitrogen supply. Ecology 85:955-962. doi:10.1890/03-0084

Owen AG, Jones DL (2001) Competition for amino acids between wheat roots and rhizosphere microorganisms and the role of amino acids in plant $\mathrm{N}$ acquisition. Soil Biol Biochem 33:651-657. doi:10.1016/S0038-0717(00) 00209-1

Persson J, Hogberg P, Ekblad A, Hogberg MN, Nordgren A, Nasholm T (2003) Nitrogen acquisition from inorganic and organic sources by boreal forest plants in the field. Oecologia 137:252-257. doi:10.1007/s00442-003-1334-0

Raab TK, Lipson DA, Monson RK (1999) Soil amino acid utilization among species of the Cyperaceae: plant and soil processes. Ecology 80:2408-2419

Recous S, Aita C, Mary B (1999) In situ changes in gross N transformations in bare soil after addition of straw. Soil Biol Biochem 31:119-133. doi:10.1016/S0038-0717(98) 00113-8

Runge M (1970) Untersuchungen zur Bestimmung der Mineralstickstoff-Nachlieferung am Standort. Flora 159: 233-257

Schimel JP, Bennett J (2004) Nitrogen mineralization: challenges of a changing paradigm. Ecology 85:591-602. doi:10.1890/03-8002

Schimel JP, Chapin FS (1996) Tundra plant uptake of amino acid and $\mathrm{NH}_{4}{ }^{+}$nitrogen in situ: plants compete well for amino acid N. Ecology 77:2142-2147. doi:10.2307/2265708

Schimel JP, Jackson LE, Firestone MK (1989) Spatial and temporal effects on plant microbial competition for inorganic nitrogen in a California annual grassland. Soil Biol Biochem 21:1059-1066. doi:10.1016/0038-0717(89) 90044-8
Schmidt S, Stewart GR (1999) Glycine metabolism by plant roots and its occurrence in Australian plant communities. Aust J Plant Physiol 26:253-264

Sorensen PL, Michelsen A, Jonasson S (2008) Ecosystem partitioning of ${ }^{15} \mathrm{~N}$-glycine after long-term climate and nutrient manipulations, plant clipping and addition of labile carbon in a subarctic heath tundra. Soil Biol Biochem 40:2344-2350. doi:10.1016/j.soilbio.2008.05. 013

Streeter TC, Bol R, Bardgett RD (2000) Amino acids as a nitrogen source in temperate upland grasslands: the use of dual labelled $\left({ }^{13} \mathrm{C},{ }^{15} \mathrm{~N}\right)$ glycine to test for direct uptake by dominant grasses. Rapid Commun Mass Spectrom 14:1351-1355. doi:10.1002/1097-0231(20000815) 14:15<1351::AIDRCM23>3.0.CO;2-9

Thornton B, Robinson D (2005) Uptake and assimilation of nitrogen from solutions containing multiple $\mathrm{N}$ sources. Plant Cell Environ 28:813-821. doi:10.1111/j.1365-3040. 2005.01332.x

Vitousek PM, Howarth RW (1991) Nitrogen limitation on land and in the sea - How can it occur. Biogeochemistry 13:87115. doi:10.1007/BF00002772

Vitousek PM, Aber JD, Howarth RW, Likens GE, Matson PA, Schindler DW, Schlesinger WH, Tilman DG (1997a) Human alteration of the global nitrogen cycle: sources and consequences. Ecol Appl 7:737-750

Vitousek PM, Mooney HA, Lubchenco J, Melillo JM (1997b) Human domination of earths ecosystems. Science 277:494-499. doi:10.1126/science.277.5325.494

von Felten S, Buchmann N, Scherer-Lorenzen M (2008) Preferences for different nitrogen forms by coexisting plant species and soil microbes. Ecology 89:878-879. doi:10. 1890/07-1015.1 Comment

Warren CR (2006) Potential organic and inorganic N uptake by six Eucalyptus species. Funct Plant Biol 33:653-660. doi:10.1071/FP06045

Warren CR, Adams PR (2007) Uptake of nitrate, ammonium and glycine by plants of Tasmanian wet eucalypt forests. Tree Physiol 27:413-419

Weigelt A, Bol R, Bardgett RD (2005) Preferential uptake of soil nitrogen forms by grasland plant species. Oecologia 142:627-635. doi:10.1007/s00442-004-1765-2

Xu XL, Stange CF, Richter A, Wanek W, Kuzyakov Y (2008) Light affects competition for inorganic and organic nitrogen between maize and rhizosphere microorganisms. Plant Soil 304:59-72. doi:10.1007/s11104-007-9519-7 